\title{
急しゅんインパルス電圧による平等電界 ギャップの火花形成時間について
}

\begin{tabular}{|l|}
\hline 論 文 \\
\hline $53-A 28$ \\
\hline
\end{tabular}

\author{
正員 高木 勝 正 (電総研) \\ 正員 堀 井憲 爾 (名古屋大)
}

\section{1. まえがき}

近年, 配電設備の強化拡充に伴い，供給信頼度の面 から雷害防止対策が強く要望されている。しかし，配 電系統の機器破損事故をみると, 従来の雷撃主㸡電节 一ジの特性からは推論できない埸合むかなりあるとこ ろから，Griscom 氏(1)が提晶した Prestrike 電流に よる急し版波成分考慮して，事故の実態について の調查研究 ${ }^{(2)(3)}$ が行なわれている。このような経緯か ら，筆者ら秀配電線路の絶縁協調老対鲙として，機器 単体の急しゅ几波に対する破壊および放電特性につい て種々の検討を行なってきだ(4)(5)。その結果，急しゅ ん波領域においては，気中ギャップおよび誘電体表面 のフラッシオーバ電圧が, 印加電圧の波頭しゅ九度と 火花形成時間の関倸に依存して，著しく上昇すること が確加られた。これらの事実加ら，急しゅんインパ ルス電压に対するフラッシオーバの機蓝を觉明してお くことは，配電線路の総合的な雷害防止対策を確立す るうえに極めて重要なことである。

直角波インパルス電圧任対する気中ギャップのフラ ッシオーバに関しては，すでに Fletcher 民(6)がns 領 域の火花形成時間について理諭的な検討を行ない，用 加電界之火花形成時間の関倸か $0.5 \sim 50 \mathrm{~ns}$ の䇥国に 扎て，実験值と良く一致することを確加ている。 また，単極性インパルス電生に対する球ギャップの火 花形成時間に関しては, Kind 氏 ${ }^{(7)}$ の等面積法による 解析結果が報告されている。

そこで，筆者らは実線路によく現われる電圧波形を

Considerations of Formative Time Lag of Uniform-Field Gaps under Steep-Front Impulse Voltages. By Katsumasa Takagi, Member (Electrotechnical Laboratory, Ministry of International

Trade and Industry) \& Kenji Horii, Member (Faculty of Engineering, Nagoya University).

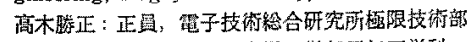

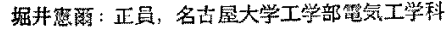

昭 $53-4$
対象として，急しゅん雷インバルス電圧の波頭を直線 上昇波で近似した場合の平等電界ギャップのフラッシ オーバ電界と火花形成時間の関係老従来の考元方を搪 張して定量的に考察を行ない，その関係の部算手法を 開発し，計算結果之実験結果の比較検討を行なった。

その結果, ギャップ長が $0.3 \sim 0.7 \mathrm{~cm}$ の管团では, 火花形成時間加 $0.06 \mu \mathrm{s}$ 以上の領域で計算值之実験值 が良く一致することが確かめられた。しかし，気中フ ラッシオーバの $V-t$ 曲線が上昇する $0.06 \mu \mathrm{s}$ 以下の 火花形成時間の領域ては，正，負ストリーマの進展時 間市よび陰極点形成などのストリーマ成長のための時 間が然視できなくなるために，計算値と実駼值の間に 次第に差が現わ机るという與味ある結果が得られた。 またギャップ長が $0.1 \mathrm{~cm}$ 比なると計算結果亡実験 結果が一致しなくなるととから，なだれのストリーマ 移行までの限界長について検討学行ない，ストリーマ 破壊加成立するのに必要な有効電子の発生電界を推定 し，てれを考虑した計算手法を開発した。更に，てれ らの計算手法を $6 \mathrm{~cm}$ の長ギャップ領域に適用したと ころ，実験結果と良く一致することが雅かるられた。

以上の検討結果加，本手法肪実用的に急しゅ九1 ンパルス電圧に対する平等電界ギャップの $V-t$ 特性 推定に十分適用できることが明らかとなったのでそ の概要を報告する。

\section{2. 実験回路および実験方法}

第1 図に実験回路を示す。图で $r_{v}, C_{v}$ は印加電圧 の波颛長を調整するための抵抗およびコンデンサであ b， $R_{1}, R_{2}$ は $1.1 \mathrm{~ns}$ の応答特間老有す万電圧測定用 の円筒状ソリッド抵抗分王器である。B.O.は $7 \mathrm{~ns} の$ ライズタイムを有する Tektronix 507 形オシロスコ ープを使用し，测定ケーブルは分王波形の娍衰扰上び 変わいをできるだけ少なくするように，長さ $1.5 \mathrm{~m} の$ 


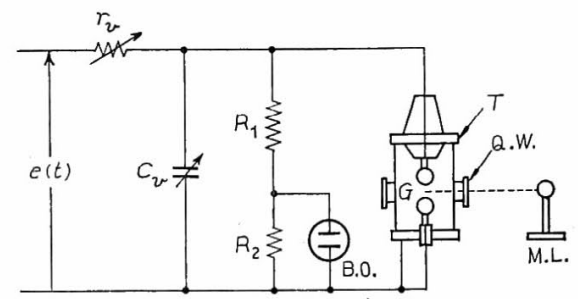

$r_{v}, c_{v}:$ 波頭調整用の抵抗およびコンデンサ

$R_{1}, R_{2}$ : 円筒状ソリッド抵抗分圧器(レスポンス時間 : $1.1 \mathrm{~ns}$ )

B.0. : Tektronix 507形オシロスコープ(ライズタイム:7ns)

$T$ : 四筒肜密閉タンク

$G$ : 球対球笔板 (直径: $30 \mathrm{~mm}$ )

M.L. : 水銀ランプ $($ LHL-30)

Q.W.:石 英 空

第 1 図実験回路

Fig. 1. Experimental circuit.

$7 \mathrm{C} 2 \mathrm{~V}$ 形高周波同軸ケーブルを用いて，フラッシオ 一バ電圧の測定を行なった。Tは実験装置であり, 気 圧を変えることを考虑して，軟鋼製の円筒形密閉タン ク (内径: $260 \mathrm{~mm}$, 高さ: $315 \mathrm{~mm}$, 容皘: $20 l$, 耐圧 : $10 \mathrm{~atm}$, 内面クロムめっき) を使用し, 直径 $30 \mathrm{~mm}$ のステンレス鋼製の球対球電極 $G$ をタンク内に垂直 に配置した。電極への紫外線照射は LHL-30 形水銀 ランプ M. L. を使用し，タンクの石英空Q.W. を通し て照射を行なった。その際，供試ギャップに $3 \sim 6 \mathrm{kV}$ の正極性直流電圧を印加して, 振動容量形微少電流計 (Takeda 製, TR-84B 形)により光電流の測定を行な ったととろ， $7 \times 10^{-11} \mathrm{~A}$ 程度の值が得られた。従って ns あたりほほ 1 個の電子が陰極上に現われることに なるので，本実験の波頭長の範团においては，十分な 初期電子が供給されるとして，照射量の影響を考虑す る必要はない屯のと考えられる。なお，照射しない場 合は初期電子の出現に関係する統計的火花の遅れのた め, フラッシオーバ電圧は大きく変動することを確認 している。また, タンク内は調整なしの大気圧空気で 実験を行なったので, JEC-187-1973(インパルス電圧 電流試験一般) (8) に従って標準大気条件下ヘフラッシ オーバ電圧の補正を行なった。

実験方法は，波頭長を $0.02 \sim 1 \mu \mathrm{s}$ 間で変化させなが ら，一つの波頭長の正極性直線上昇波について電圧を 供試ギャップに連続 5 回印加し，フラッシオーバ電圧 と電圧立上り時刻からフラッシオーバまでの時間（以 後, 単にフラッシオーバ時間と呼ぶ)関係を求めた。 ギャップ長は，0.1〜0.7cm の筙囲について求めた。

なお，第 2 図には急しゅんインパルス電圧によるフ ラッシオーバ時のオシグラムの一例を示した。図のオ シログラムでギャップがフラッシオーバした後の電圧 值が零とならないのは，フラッシオーバ波形が急しゅ

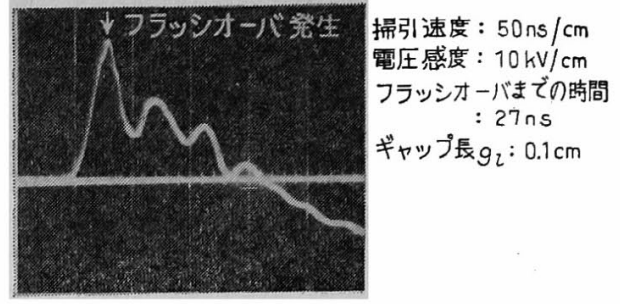

第 2 図 フラッシオーバ波形の一例

Fig. 2. An example of flashover voltage waveform.

ん波頭領域のものであるため，接地線のインピーダン ス降下が影響しているととによるあのである。

\section{3. 実験結果とその考察}

第 3 図は代表例として, ギャップ長が $0.1,0.3,0.5$ および $0.7 \mathrm{~cm}$ の $V-t$ 曲線をばらつきの範囲と平均 值の関係で示したものである。図から，フラッシオー バ電圧はフラッシオーバ時間が短くなるに従って，す なわち電圧の波頭しゅん度を大きくするに従って上昇 の傾向を示し，いずれのギャップ長においても，ほほ

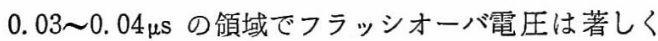
上昇するようになる。この原因は, ギャップの火花形 成時間と印加電圧のしゅん度に基づくことについては これまでにあ報告(5) したところである。しかし，V$t$ 曲線が急上昇する時間領域での各ギャップ長に対す る曲線傾向をみると, ギャップ長が $0.1 \mathrm{~cm}$ の場合は フラッシオーバ時間が $0.028 \mu \mathrm{s}$ 付近で, ほぼ直線状に 上昇しているが， $0.3,0.5$ および $0.7 \mathrm{~cm}$ の場合は上 昇に傾斜を持つようになり，しかむギャップ長が長く なるほどその傾きが小さくなる。一方，ギャップのフ

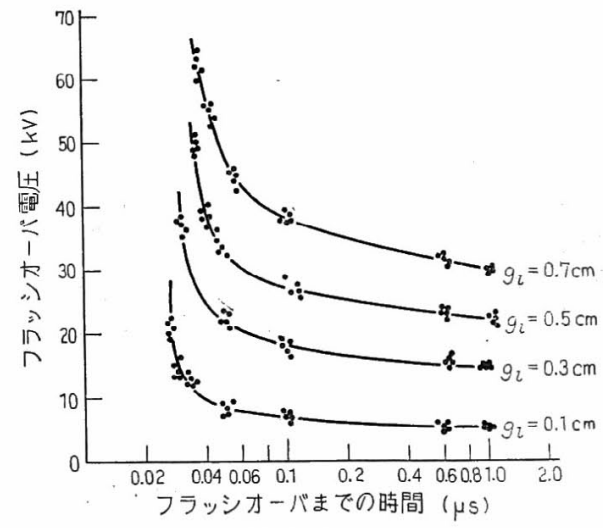

第 3 図 正極性直線上昇波電圧による 球ギャップのフラッシオーバ特性

Fig. 3. Flashover characteristics of spheregaps for positive linearly rising voltages. 


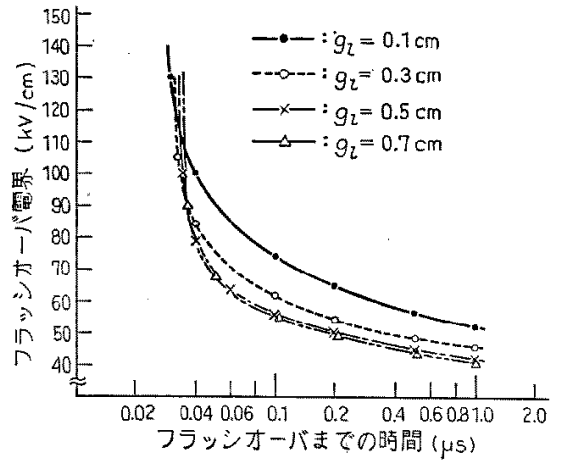

第 4 図 フラッシオーバ電界とフラッシ オーバ時間の関係

Fig. 4. Relation between flashover field and time to flashover.

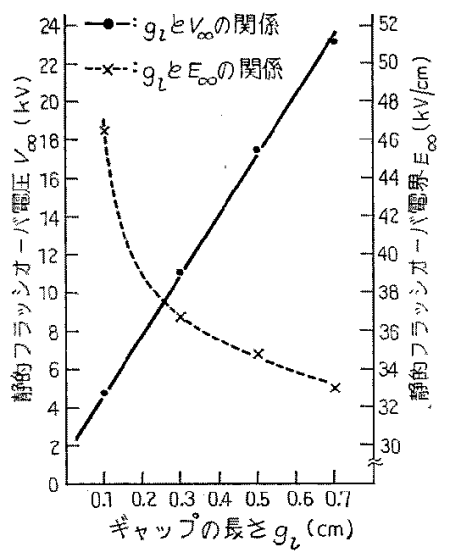

第 5 国 ギャップの長さと静的フラッシオーバ

電圧求よび静的フラッシオーバ電界の関㳢

Fig. 5. Relation between gap length and static flashover voltage, and static flashover field.

ラッシオーバ電界に対してフラッシオ一バ時間の関係 を整理すると第 4 図のようになる。国加ら、ギャップ 長が長くなるほどフラッシオーバ電界が低くなる傾河 があるが，短時間のフラッシオーバ領域では，キ゚ャッ プ長によらずに同じようにフラッシオーバ電界が急上 昇している。このととは，フラッシオーバ電界が高く なると，火花形成時間はギャップ長によらずには隹に一 定となることを示唆しているあのであり，後述のスト リーマがフラッシオーバまで成長するための時間と詨 比して，興味ある結果である。

また，図からフラッシオーバ電界が $90 \sim 100 \mathrm{kV} / \mathrm{cm}$ 以下の領域では， $0.7 £ 0.5 \mathrm{~cm}$ の曲線はほぼ一致し ているが， $0.5,0.3,0.1 \mathrm{~cm}$ とギャップ長が短々なる に徉って $0.7 \mathrm{~cm}$ の曲線加らのずれが大きくなってい る。これは第5図に示すように，各ギャップ長に対応

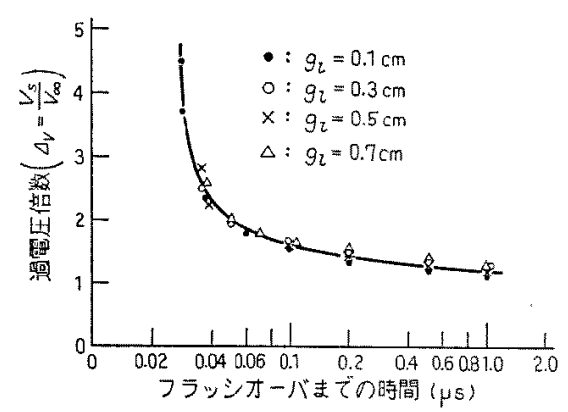

第 6 図 過電圧倍数よフラッシオーバ時間の関係

Fig. 6. Relation between impulse ratio and time to flashover.

する静的フラッシオーバ電生（ここでは，直流フラッ シオーバ電壬を静的フラッシオーバ電生と呼ぶ）の值 が，原点を通らない直線しなることに対応する。これ を静的フラッシオーバ電界の閣係で示すと図の点線の ようになりギャップ長が小さくなるに従ってフラッ シオーバ電界の増加が著しくなっている。これらのこ とから，V-t曲線の電在檕目盛点静的フシッシオーバ 電生で規格化すれば，ギャップ長によらずに一定の曲 線で表わされるととが予想される。

第 6 困は静的フラッシオーバ電Eとフラッシオーバ

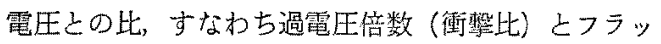
シオーバ時間の関係を示すあのである。四から，各ギ ヤップ長に対応する点は予想したとおり，ほぼ同一曲 線上にのっていることから，過電压倍数がフラッシオ 一八時間に支配的に影響を及活すこと加わ加る。

\section{4. 火花形成時間の検討}

$\langle 4 \cdot 1\rangle$ 火花形成時間の計算手法一般汇大気圧 平等電界ギャップの破買は，ギャップ内の臨界距離ま で単一電子なだれが進行して，なだれ頭部の電子数が 臨界值 $N_{c}\left(10^{8} \sim 10^{9}\right.$ 個程度) に達すると，ストリーマ への転热采件が満たされて，いかゆるストリーマ破壤

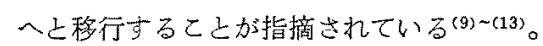

本实験のように，インパルス過電圧印加の場合は， 特になだれからストリーマへの変掺が起りやすく， ス トリーマの急速な焦展によりフラッシオーバが完成さ れる。このような破買過程におけるフラッシオーバ時 間（通常の火花形成時間はフラッシオーバ臨界電匡を 越えた時間かららフラッシーバまでの時間として定義 されるが，こてでは奏験結果との刘五から前記のよう に定義した)に閶しては種々の期討結果が報告(6)(9)(14) されているが，いずれ電子なだれが成長してストリ 一マに転換するまでのなだれ走行時間をもって、フラ ッシオーバ時間しするととについては大差ないようで 


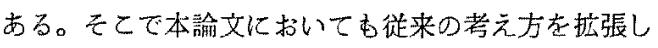
て, フラッシオーバ時間の計算手法を検討すると以下 のようになる。すなわち,フラッシオーバ時間 $t_{F}$ 内で

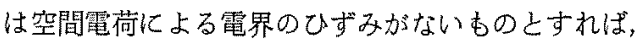
$t_{F}$ までになだれ頭部に生成される電子数 $N_{C}$ は

$$
N_{C}=\exp \alpha v-t_{F}
$$

で表わすことができ， $N_{C}$ ，衝突電離係数 $\alpha$, 雷子の 移勳速度 v-の值加法まれば $t_{F}$ の值を求めることが

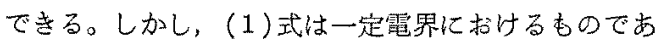
り，本春験では直楾上昇波電生を用いているので，印 加電界仕 (2) 式に示すように時間 $t$ の関数となり，雷 界隹存する $\alpha$ 扰よ゙ $v-$ 李当然時間の関数上なる。

$$
E(t)=E_{S} \cdot t / t_{F} \quad \text { ただし } 0 \leqq t \leqq t_{F}
$$

ここで， $E_{S}$ はフラッシオーハ電界である。とのよ うな印加電界に対してのフラッシオーバ時聞 $t_{F}$ は, (1)式在次式のように暳き換えることによって求める ことができる。

$$
\ln N_{C}=\int_{0}^{t_{F}} \alpha\left(E_{S} \cdot t / t_{F}\right) v_{-}\left(E_{S} \cdot t / t_{F}\right) d t \ldots
$$

しかし，第 3 章で述べたように，静的フラッシオー バ閶圧に対する過電任倍数がフラッシオーバ時間に関 与するもの上すれば，直線上昇波電庄が対応するギャ ップの静的フラッシオーバ電生に到達した時点で，陰 極上に現われた電子が破㙼に有效に奇与するとして， (3)式の積分限界を決めるのが奖当であると考元られ る。すなわち，静的フラッシオーバ電界以下では電子 が電界に加速されてギャップ間を走行してあ，電子な だれをストリーマまで成長させるには至らないものと 考えら机る。このような観点加ら，（3)式の積分限界 を直線上暑波電圧が静的フラッシオーバ電王に到達し た時刻からフラッシオーバ時間までとすれば，（3)式 の程分限界は次式のようになる。

$$
\ln N_{C}=\int_{\left(E_{w} / E_{S}\right) t_{F}}^{t_{F}} \alpha\left(E_{S} \cdot t / t_{F}\right) v_{-}\left(E_{S} \cdot t / t_{F}\right) d t
$$

ここで， $E_{\infty}$ は静的フラッシオーバ霆界を示す。

(4)式加ら $t_{F}$ を求めるために， $\alpha$ 扰よび

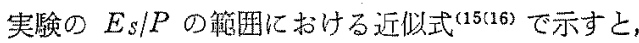

$$
\begin{aligned}
& \alpha / P=A \varepsilon^{-B(P / E(t))} \\
& v_{-}=K-V \overline{E(t)}
\end{aligned}
$$

となる。 $A, B$ 扣よび $K$ 一は鼠験加ら求まる係数执よ び指数であり，Pは気生である。そこで，(5)式扔よ び(6)式を(4)式に代入すると,

$$
\ln N_{C}=P A K-\left(\frac{E_{S}}{t_{F}}\right)^{1 / 2} \int_{\left(E_{\infty} / E_{S}\right) t_{F}}^{t_{F}} \varepsilon^{-(\beta / t)}
$$$$
\times t^{1 / 2} d t
$$

となりとれを解けば

$$
\begin{aligned}
\ln N_{C}= & \frac{2}{3} P A K-\left(\frac{E_{S}}{t_{F}}\right)^{1 / 2}\left\{\left(\frac{\Delta}{t_{F}}\right)^{-(1 / 2)}\right. \\
& \times \varepsilon^{-\left(\beta \Delta / t_{F}\right)}\left(2 \beta-\frac{t_{F}}{\Delta}\right)-\left(\frac{1}{t_{F}}\right)^{-(1 / 2)} \\
& \times \varepsilon^{-\left(\beta / t_{F}\right)}\left(2 \beta-t_{F}\right)+2 \sqrt{\pi} \beta^{3 / 2} \\
& \times\left(\frac{2}{V} \frac{2}{\pi} \int_{0}^{\sqrt{\Delta \beta / t_{F}}} \varepsilon^{-X^{2}} d X\right. \\
& \left.\left.-\frac{2}{V \pi} \int_{0}^{\sqrt{\beta / t_{F}}} \varepsilon^{-X^{2}} d X\right)\right\} \ldots . .(8)
\end{aligned}
$$

が得られる。ここで, $\Delta=E_{S} / E_{\infty}, \beta=B P t_{F} / E_{S}$ であ る。しかし，(8)式は $t_{F}$ に関す吕解析解とはならな いので，棓算機を用いて本実驗の範囲における数值解 析を行なうと，次節に示す結果が得られる。なお，以 上の計算手法には電子の拡散の効果は考慮していない が，後述の計算結果にもみられる上うに，夷験結果の フラッシオーバ時間が 0.06〜1 1 0 の領域において計算 結果とよく一致するところから，工学的には問題ない ものと考えられる。

〈4.2〉 フラッシオーバ時間の数值解析 数值計

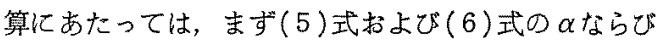
にひーの係数 $A, B, K$ 一選定しなり妃ばならない。 $\alpha$ に関しては，乙れまで Sanders ${ }^{(17)}$ の值が多く使用 されてきたが，ここでは，電子の付着も考滤して Geballe-Harrison ${ }^{(18)}$ (以下 G-H と略称する) によっ て測定された等洒電離指数 $\alpha^{\prime}=\alpha$ ク圭用いることに した。第7図・卵は $\mathrm{G}-\mathrm{H}$ による $P / E_{S}-\ln \alpha^{\prime} / P$ の 関係 $\left(E_{S} / P\right.$ および $\alpha^{\prime} / P$ の目盛も併示) 走すすの である。四から， $\alpha^{\prime} / P$ の測定点は $E_{S} / P$ が $60 \mathrm{~V} / \mathrm{cm}$ ・Torr までなので，本笑験の筑罒 $\left(E_{S} / P=56 \sim 180 \mathrm{~V} /\right.$ $\mathrm{cm}$-Torr) K䧟合する係数 $A, B$ を求めるには，乙れ らの湘定点加ら外をうして罗当と思加㧈直線を推定 しなけ机ばならな。しかし，低い $E_{S} / P$ の領域にお ける圂線索高い $E_{S} / P$ の領域票で外そうすることの妥 当性については，検璟を要する問題である。

そこで， $E_{S} / P$ が高くなるに徒って付着の影響が小 さくなるとと老考慮して, Sanders ${ }^{(17)}$ (O盺), Mash ${ }^{(19)}$ ( $x$ 印) 找起 Townsend ${ }^{(20)}(\Delta$ 印) 氏 られた $\alpha / P$ の值を第7图にプロットし，三者の平均 的な直線龙引き， $\mathrm{G}-\mathrm{H}$ の測定点加ら外そうされる直 線を引くし，雨直線は $E_{S} / P$ が $80 \mathrm{~V} / \mathrm{cm}$ ・Torr を境と して若下傾斜の異なる折れ線で表わすこよができる。

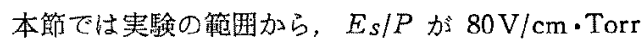
以上の推定直線を用いて係数 $A, B$ 龙的ると， $A=$ $14.81 / \mathrm{cm}$. Torr, $B=326 \mathrm{~V} / \mathrm{cm}$ ・Torr の值を得る。 v-に関しては，一般に大気圧付近のフラッシオーバ 


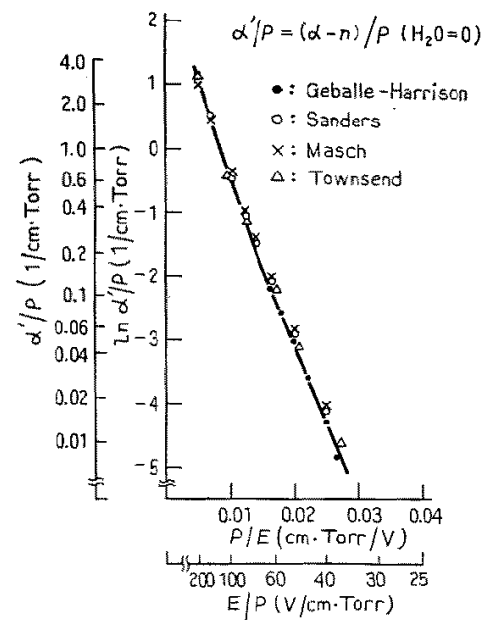

第 7 困 空気の $E_{S} / P$ \& $\alpha^{\prime} / P$ の関係

Fig. 7. Values of $\alpha^{\prime} / P$ as a function of $E_{S} / P$ in air.

電界に近い值では，電然 $E_{S}(\mathrm{kV} / \mathrm{cm})$ に対し， $v_{-}$ $0.224 \times 10^{7} V \overline{E_{S}}(\mathrm{~cm} / \mathrm{s})$ が用いられているので(21)，K. $=0.224 \times 10^{7} \mathrm{~cm} / \mathrm{kV} \cdot \mathrm{s}$ を使用した。

次に，電子なだれからストリーマ移行の条件が渾た されるなだれ先蝡の電子数の政界值 $N_{C}$ は $10^{8}$ 個を 用いた。この值は第 8 図のフラッシオーバ時䦧の計算 例（ギャップ長が $0.7 \mathrm{~cm}$ の場合在示す）に見られる ように，例え $10^{9}$ 個あるいは $10^{10}$ 個になったとして 6，フラッシオーバ時間における差は 11〜13\% 程度 にすぎないので，大勢に影響枯ないようである。しか

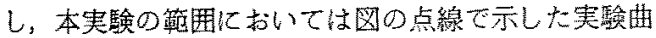
線に見られるように，108 個しした方がより良い一致

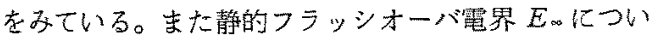
ては，第5図に示した各ギャップ長に対応する值を用 who

凶上の数值を用いて，フラッシオーバ電界とフラッ

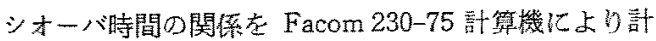
算を行なった。

〈4.3〉計算結果と突験結果の比較検討 第 9 図 (a)〜 (d)は各ギャップ長に対するフラッシオーバ時

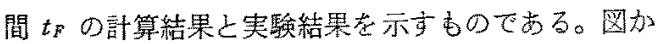
ら， $0.3 ， 0.5$ 姑よひ $0.7 \mathrm{~cm}$ のギャップ長でば，フラ ッシオーバ電界 $E_{S}$ が $60 \sim 70 \mathrm{kV} / \mathrm{cm}$ 可ては計尊

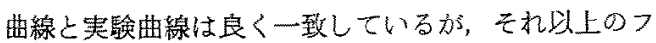
ラッシオーバ䉓界になると両曲線の間に次第に差が見 われるようになる。として，実験に上るフラッシオー バ時間が $0.03 \mu$ 付近てほぼ一定となるのに効し，計 算值は減少を続ける。これは、計算では電子なだれの

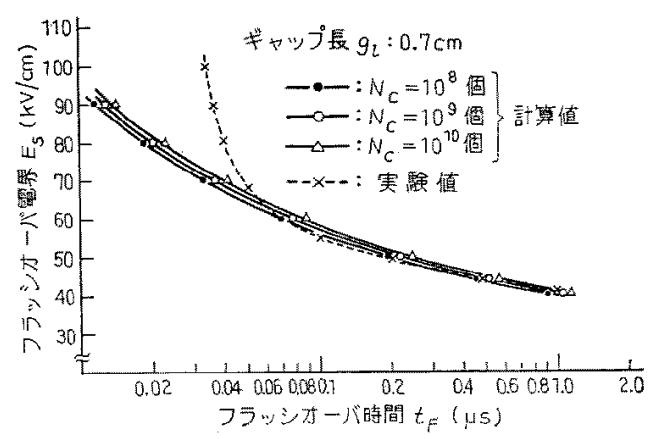

第 8 㘡 フラッシオーバ時間の計算值に 及倿す電子数の臨界值の影響

Fig. 8. Influence of critical number of avalanche electrons on the calculated values of time to flashover.

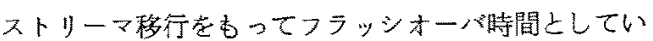
るが，奏際にフラッシオーバが生ずるには鳥山民ら ${ }^{(22)}$

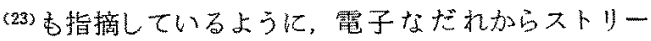

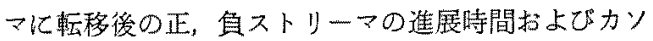
ードホールの形成，プラズマの加熱などにある时間を 要するためと考えられる。同様に，低電界領或で香し の効果は含まれるわけ方るが，ストリーマ移行まて の時間が長いために兒かけ上その効果が現かれないす のと解瀵される。とれに対し $0.1 \mathrm{~cm}$ のギャップ長に なると（a）図に見もれるように低電界領域でる暲 曲線と奏験曲線しの間代差が生ずる上うになる。この 原因については次節て検討するが，実験曲線が $0.03 \mu \mathrm{s}$ 付近で一定となることについては，前三者とほほ変わ りなとこるでるる。これらの事害から，高電界下の フラッシオーバ特間関しては，ストリーマの進展時 間および陵極点形成などのストリーマがラッシオー

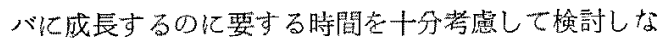
壮机けららな。

\section{〈4.4〉ストリーマ破壊となだれ限界長の関係}

前述したように，本手法によるフラッシオーバ時間 の計算曲線し実駼曲線は，0.1cmのギャップてはかな りの盖を生ずるととが磼かめられた。

このこしは，ギャップ長が $0.1 \mathrm{~cm}$ 以下になると氮

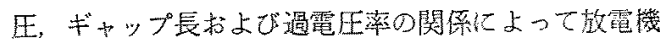
構が翼なるために一致しなくなるものか，むるい仕を の他の原因尤るもの加ついて检討して报くこをは

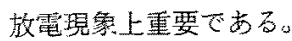

ここて，放電域に闒して，森氏(24)によって求められ

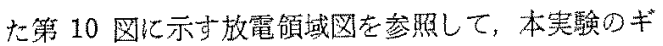
ヤップ長 $0.1 \sim 0.7 \mathrm{~cm}$ の $V-t$ 曲線の測定点(第 3 图参

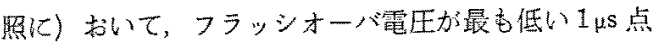



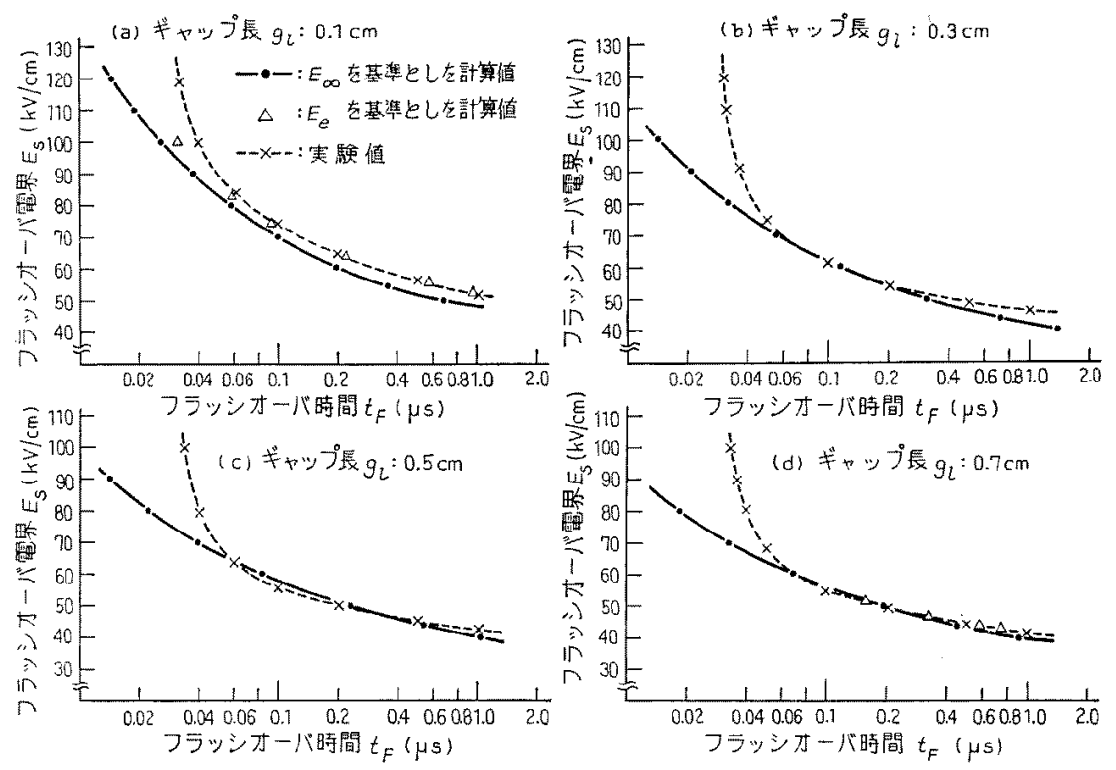

第 9 図 フラッシオーバ時間の計算侹と実験值の比較

Fig. 9. Comparison of calculated and measured values of time to flashover.

の過電圧率 $\Delta V$ と $p q$ ，の関係を第 10 図に白丸印て プロットし，乙れを限界曲線と比较 $(A)$ するる， 0.3 〜0.7cmのギャップ長については，いずれるストリー 湤電域の条件在十分満足している。しかし， $0.1 \mathrm{~cm}$ のギャップ長になる之，三好氏 ${ }^{(24)}$ 亿上って求如られ た限界条件 $(B)$ の若干下側にプロットされるという結 果になっている。しかし，タウンゼント放笔域とスト リーマ放電域の限界は実験条件によって，相当広篹囲 な領域となることが指摘されており，一応ここでは単 一電子なだれ加らストリーマの転換により，フラッシ オーバが起るすの之侾えて話を進める。

そこで，前述の実験とのくい違いの原因を究明する ために，まず筆一電子なだれからストリーマ移行まで

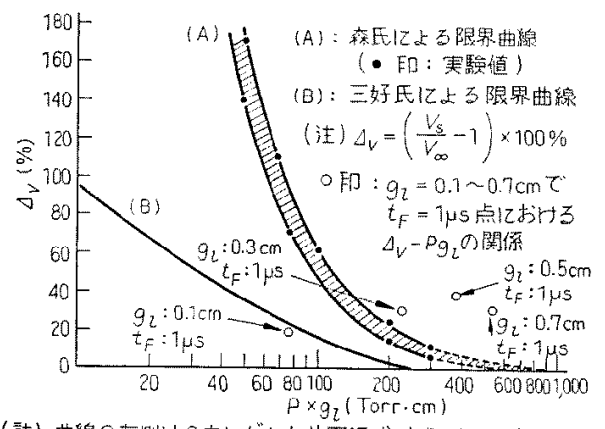

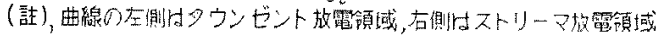

第 10 図放電領域図

Fig. 10. Relation between $P \cdot g_{t}$ and $\Delta v$.
のなだれの限界長 $Z_{0}$ を計算し，各ギャップ長 g に 対して $Z_{0} \leqq \theta ＼mathrm{~ の 条 件 か ゙ 湍 足 さ れ て い る か と ゙ う か ゙ 検 ~}$ 討した。

なだれの限界長 $Z_{0}$ はなだれ進行速度の時間琴分と して，次式から計算するととができる。

$$
Z_{0}=\int_{\left(E_{\infty} / E_{S}\right) t_{F}}^{t_{F}} v-\left(E_{S} \cdot t / t_{F}\right) d t
$$

ここで，フラッシオーバ時間の計算と同様に $K-V \bar{E}$ と扔いて，上式を積分すれば，

$$
Z_{0}=\frac{2}{3} K_{-t_{F}} E_{s}{ }^{1 / 2}\left[1-\left(\frac{E_{\infty}}{E_{S}}\right)^{3 / 2}\right]
$$

となる。

(10)式を用いて各ギャップ長に対する $Z_{0}$ を計算す ると，符 11 図の関係が得られる。図で实線は $t_{F} の$ 計算健在用いて $Z_{0}$ を求めたものであり，点線は $t_{F}$ の 実戨值加求めた $Z_{0}$ の值である。図から，0.3 0.7 $\mathrm{cm}$ のギャップ長においては，電界が低くなるに従っ て $Z_{0}$ 㹥著しく增加する傾向を示し， $Z_{0}>g_{6}$ の関係之

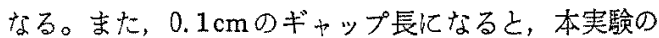
全領域にわたって $Z_{0}>g_{1}$ の関保となってしまう。

なだれの限界長の関係が満足されないととを考虔す ると，本実験の場合のストリーマ機構纪ついて再検討 を必要とするこ之が示㗜される。すなわち，本手法は 四加電界が静的フラッシオーバ電界に到達した時点て 陰極上に現わ机た電子が破壊に有効们寄与するとして フラッシオーバ時間の計算を行なった。ところが，第 

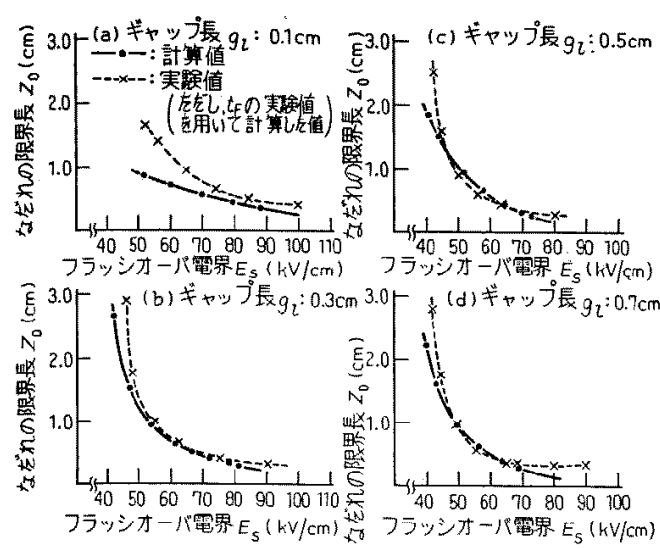

第 11 図 フラッシオーバ電界となだ机の 限界長の関係

Fig. 11. Relation between flashover field and limit length of an avalanche.

11 图のように $E_{\infty}$ を基準しして計算した $t_{F}$ を用い て $Z_{0}$ 在求斊，いずれのギャップ長に扔いても， ギャップ長 $g_{l}$ 在越えたところでストリーマ移行の条 件である電子個数の臨界值 $N_{C}$ に迳する場合があると いう不合理な結果が得られたわけである。このことは ギャップ長およびフラッシオ一バ電界が小さくなる と，ストリーマ破壇を生ずるのに有効な電子の発生電 界を $E_{\infty}$ 之考无るのは妥当でないこと走示㖫している ものである。つまりE。で除極上に現われた電子はギ ャップ間を走行して屯距離が短いために電子個数を $N_{C}$ に電離增殖するには至らず，更に䁒加電界が上昇 した時点で陰極上に現われた電子がちょうど $Z_{0}=g_{l}$ の距離で単一電子なだれ頭部の電子個数を $N_{C}$ に増 殖して、ストリーマ破壤加生ずるものと考えられる。

このような観点加ら，まず計算結果と夷験結果よの 間㳊星大きな差が現かれた $0.1 \mathrm{~cm}$ のギャップ長に ういて，各種の波頭長四加要正に対してなだれの限界

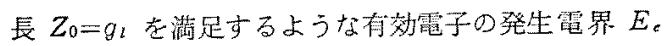
をカットアンドトライで求めた。しれ在用いて，(8)

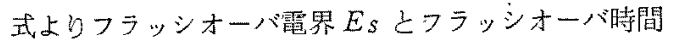

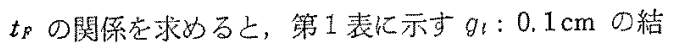

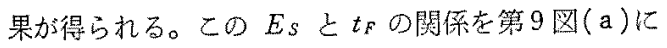
プロットすると $\Delta$ 印のようになり，祙が $0.06 〜 1 \mu \mathrm{s}$

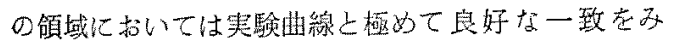
るようになる。しかし，実験曲線吕急上昇する領域厄 は，計算結果 $\left(t_{F}: 0.031 \mu \mathrm{s}, E_{s}=101 \mathrm{kV}\right)$ 亿も睍ら れるように両者の間に差が生ずるようになる。このこ とは〈4.3〉節で指摘したように， $V-t$ 帆線が急上年す

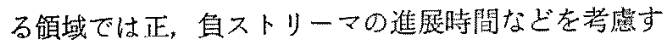

第 1 表なだれの限界長を满足する $E_{\text {e }}$ よ $E_{S}$ およひ $t_{F}$ の関係

Table 1. Relation between $E_{e}$ and $E_{S}, t_{F}$ which satisfy limit length of an avalanche.

$g_{t}: 0.1 \mathrm{~cm}$ の萮合

\begin{tabular}{c|c|c|c}
\hline$S(\mathrm{kV} / \mu \mathrm{s})$ & $E_{e}(\mathrm{kV} / \mathrm{cm})$ & $E_{S}(\mathrm{kV} / \mathrm{cmi})$ & $t_{F}(\mu \mathrm{s})$ \\
\hline 54 & 52.65 & 53 & 0.981 \\
\hline 100.7 & 56.8 & 57.4 & 0.57 \\
\hline 269.3 & 62.2 & 64 & 0.216 \\
\hline 812.4 & 70 & 74.5 & 0.0917 \\
\hline 1,431 & 75.5 & 83 & 0.058 \\
\hline 3,258 & 84.5 & 101 & 0.031 \\
\hline
\end{tabular}

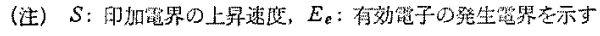

る必要のあること走唆しているあのと考究られる。

更に，上記の計算手法の妄当性を確かるるたるに， ギャップ長が $0.7 \mathrm{~cm}$ の堎合について第 11 図の結果 が $Z_{0}>g ，$ 領域の波頭長印加電国に対して $E_{s}, t_{F}$ を

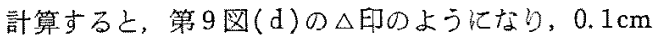
の場合之同様に $0.06 \mu \mathrm{s}$ 以上の領域に扎いては弮駼結 果と良く一致する結果加得られた。

これらのことから，有效電子の発生電界に着目すれ ば,フラッシオーバ電界とフラッシオーバ時閪の関係 は $E_{\text {os }}$ を基準しした埸合よりも実跧曲線と極めて良く 一致し，しかも，なだれの限界長の関係も渵足される

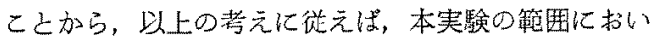
て上に述べたようなストリーマ破填機棈か成立してい る屯の上推察される。

\section{5. 本計算手法の長ギャップへの適用}

本討算手法老用いて大気压中における $0.7 \mathrm{~cm}$ まて の平等電界ギャップのフラッシオーバ㭙間を計算すれ

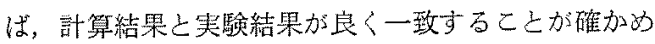
られた。ここで，本手法がどの程度のギャップ辰客で 適用できるかについて検討しておくことは害用的な面 から極めて重要である。

長ギャップの急しゅんインパルス電国に刹するフラ ッシオーバ特性に関しては，これまてに算者ら (25) ま

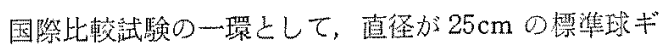
ヤップを用いて、ギャップ長 $6 \mathrm{~cm}$ に対するV-t 特

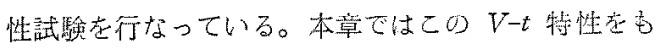

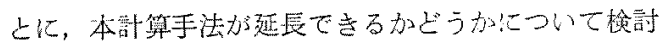
した。

第 12 区の点線は $25 \mathrm{~cm}$ 標集球ギャップのフラッシ

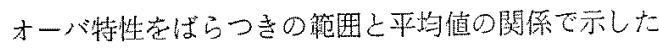
あのである。フラッシオーバ特性の奏測笔围(0.08〜1

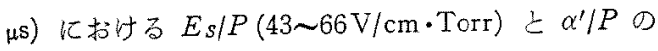

昭 $53-4$ 


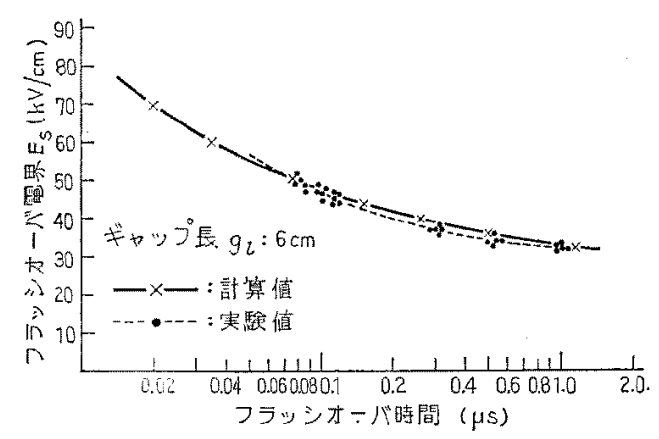

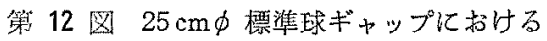
フラッシオーバ㭙間の計算と実験值の比較

Fig. 12. Comparison of calculated and measured values of time to flashover for $25 \mathrm{~cm} \phi$ standard sphere gap.

関係庆，符 7 图の $E_{S} / P$ の低い領域 $(40 \sim 80 \mathrm{~V} / \mathrm{cm}$. Torr) に的ける直線を用いて，(5)式の係数 $A, B$ を 求めると $A=9.21 / \mathrm{cm}$.Torr, $B=260 \mathrm{~V} / \mathrm{cm}$. Torr と なる。またフフラッシオーバ電界付近の電子の移動速 殿を $v$ - $0.224 \times 10^{7} V \overline{E_{S}}(\mathrm{~cm} / \mathrm{s})$ ならびに電子数の 臨界值 $N_{C}=10^{8}$ 個とし， $E_{\infty}=26.83 \mathrm{kV} / \mathrm{cm}$ を用いて

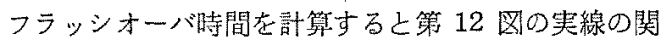
係が得ら机る。困から明らかなように，両曲線は実呀 の籍围に和いて良好な一致をみている。

な放，E。を基準としたなだ的の限界長について は，本実験の笘围に括いて $2.3 \mathrm{~cm}$ 以下となることか ら，ストリーマ破壊の条件は十分満足されている。

\section{6. むすび}

以上，気中平等電界ギャップのフラッシオーバ特性 の推定方法について検討を行なったところ, 次の事項 が明らかとなった。

(1) 単一電子なだれ頭子部の雪子数が，臨界㥀 $N_{C}$ $\left(10^{8}\right.$ 個) に達すると，ストリーマ形式の破壊が生ずる 上仮定して，面線上界波電王によるフラッシオーバ時 間を計算すると， $0.3 \sim 0.7 \mathrm{~cm}$ のギャップ長に対し， $0.06 \mu \mathrm{s}$ 队上のフラッシオーバ時間領域において実験 值と良く一致することが確かめられた。

(2) 契験によるフラッシオーバ㭙間がフラッシオ 一バ溉界に対してほぼ一定しなる急しゅん波領域にお いて，計算倬しの間に考が生ずるのは，電子なだれが ストリーマへの条件に達した後, 员にストリーマがフ ラッシオーバに成長するのに要する時間が問題上なる ことを指摘した。

(3) $0.1 \mathrm{~cm}$ 以下のギャップ長領域では, フラッ シオーバ時間の計算值と事験值が一致しなくなるとと
から，ての原因をなだれの限界長の関係から検討し， 有効露子の発生電界を考盧した計算手法について考察 した。

（4）本計算手法の適用範井について検討したとこ ろ，6cmの長ギャップについてす十分遥用できること が明らかとなった。この結果, 公称電生 $6.6 \mathrm{kV}$ 配電 線路の平等電界下に打りる気中絶縁を対象 $(6.6 \mathrm{kV}$ 配 電線路の基準インパルス絶縁強度: $60 \mathrm{kV}$ ) とすれば， $6 \mathrm{~cm}$ までギャップ長の筙用について本手法の適用の 可否を梌討して拈けば工学的に十分である。

（5）奏線路に発生する急しゅん波サージ電压の波 頭長の最大確率は $100 \mathrm{~ns}$ 程度之考えられているので (26)(27)，本手法は実用的にフラッシオーバ特性を推定 するのに極めて有効な方法である。

䅂りに，本研究に閔して有益な监助言と御批判をい ただいた当所嵒山讧太郎高エネルギー研究室長，杉浦

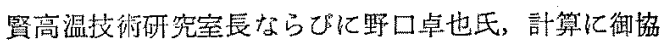
カいただいた玉田紀治氏，また大同工業大学研究会に おき出して種々御討諭を睗わりました三好保㥶教授を はじわ上する関係各位深基なる謝意を表します。 (昭和 52 年 4 月 4 日受付，同 52 年 11 月 25 日再受付)

\section{文献}

(1) S.B. Griscom: Trans. Amer. Inst. Elect. Engrs 77, pt. III. (1958)

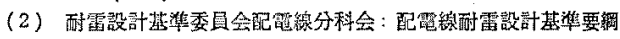
(昭 38-8)

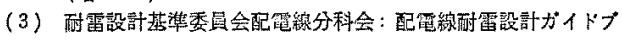
ック (炤 51-3)

(4) 高木·木下: 電学誌 91,1533 (昭 46-8)

(5) 离术: 單学諭 A, 94, 17 (昭 49-1)

(6) R. C. Fletcher: Phys. Rev. 76 (1949-11)

(7) D. Kind: Elektroteck. Zeits. 79, 65 (1958)

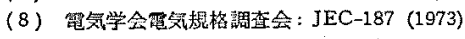

(9) 本多: 䉓学誌 85，1394 (昭 40-8)

(10) 三好: 日本物理学会綕 30,591 (招 50)

(11) 林-安藤: 雷学誌 86, 298 (炤 41-2)

(12) 宅闑·液刃：同上 90，1381 (昭 45-7)

(13) 珹父 - 川口: 同上 91，1543 (沿 46-8)

(14) G. A. Mesyats, et al. : Soviet Phys. Uspekni 15, 282 (1972)

(15) 三好：火花放電理諭入門（昭 40）笛気獒院

(16) H. Schlumbohm: Z. Phys. 182, 317 (1965)

(17) F. H. Sanders: Phys. Rev. 44, 1020 (1933)

(18) M. A. Hârrison, et al.: ibid. 91, 1 (1953)

(19) K. Masch: A.rch. Electrot ech. 26, 587 (1932)

(20) L. B. Loeb: Basic Processes Gaseous Electronics, U. of Cal. (1961)

(21) H. Raeter: Z. Phys. 107, 91 (1937)

(22) 鳥山: 靃学誌 87, 1626 (㗁 42)

(23) F. M. Merril, et al. : J. Appl. Phys. 10, 873 (1939)

(24) 菻: 電学誌 75，1156 (昭 30-10)

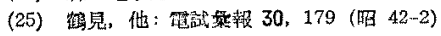

(26) S. B. Griscom, et al. : IEEE Trans. Power Apparatus Syst. PAS-84, 257 (1965-4) .

(27) 長野：四囷電力技研研﨎 No.7412 (昭 50-3) 